\title{
Stress resistance and recovery potential of culturable and viable but nonculturable cells of Vibrio vulnificus
}

\author{
Dieter Weichart $†$ and Staffan Kjelleberg $\ddagger$
}

Department of General and Marine Microbiology, Göteborg University, Medicinaregatan 9C, 41390 Goteborg, Sweden

\author{
Author for correspondence: Dieter Weichart. Tel: +44 1970623111 ext. 4187. Fax +441970622350. \\ e-mail:dhw@aber.ac.uk
}

The estuarine, human-pathogenic bacterium Vibrio vulnificus responds to low temperature by the formation of viable but nonculturable (VBNC) cells, while starvation at moderate temperatures allows for maintenance of culturability of this organism. Recovery of cold-incubated populations of $\boldsymbol{V}$. vulnificus was restricted to the culturable fraction in slide cultures and most probable number assays. These populations, however, gave between 1-1- and 8-fold higher c.f.u. counts on soft agar plates than on ordinary agar plates, indicating that a small and variable fraction of the cell population was injured rather than nonculturable. Thus, the population of cold-incubated cells is composed of culturable, injured and nonculturable cells, with the numbers of the culturable and injured cells rapidly decreasing during cold incubation. Recovery of nonculturable cells of the organism, however, could not be obtained by any combination of temperature and nutrient shifts in any of the assays. VBNC cells of the organism were assessed with regard to their persistence and stress resistance in comparison to growing and starved cells. The sonication resistance of VBNC cells was initially similar to that of growing cells, but increased during prolonged cold incubation. The final resistance of cold-incubated VBNC cells was equal to the markedly increased resistance of starving cells, which also displayed increased resistance against exposure to ethanol and mechanical stress. Our results indicate that in spite of the apparent absence of recovery under a wide range of laboratory conditions, VBNC cells of $V$. vulnificus undergo changes at low temperature which potentially allow them to persist for extended periods.

Keywords: Vibrio vulnificus, viable but nonculturable, starvation, resistance, recovery

\section{INTRODUCTION}

Environmental conditions impose a variety of stresses on micro-organisms, which in turn have developed different strategies to survive, including adaptation and escape mechanisms. In some bacteria and fungi starvation leads to the formation of spores, whereas the majority of nonsporulating bacterial species have evolved means to adapt to starvation without the complete concomitant loss of

\footnotetext{
†Present address: Institute of Biological Sciences, University of Wales, Aberystwyth, Dyfed SY23 3DA, UK.

$\ddagger$ Present address: School of Microbiology and Immunology, University of New South Wales, Sydney 2052, Australia.

Abbreviations: VBNC, viable but nonculturable; MPN, most probable number; DAPI, 4',6-diamidino-2-phenylindole.
}

activity that is observed in spores (Morita, 1993). In these species, the metabolic cost of maintaining activity throughout prolonged starvation seems to be balanced by the selective advantage of immediate growth ability. Certain stresses, however, transform non-sporulating cells into a spore-like 'dormant' state, from which they cannot readily recover (Kaprelyants $e$ t al., 1993). Cells which are not culturable in standard media but retain certain features of living cells such as respiratory activity (Zimmermann $e t$ al., 1978) and substrate uptake (Kogure et al., 1979) have been termed 'viable but nonculturable' (VBNC). The VBNC state has been proposed to represent an escape strategy for survival (Colwell et al., 1985; Roszak \& Colwell, 1987), and a large number of bacterial species, including many important pathogens, have been reported to enter VBNC states under laboratory or field conditions (Oliver, 1993). 
The pivotal question at present appears to be what significance VBNC cells have in the environment with regard to ecology, epidemiology or pathogenesis (Barer $e t$ al., 1993). In this respect, the most controversial issues are whether VBNC cells can persist and whether they can regain growth capability and infectivity. While several papers have reported resuscitation of VBNC cells (AllenAustin et al., 1984; Grimes \& Colwell, 1986; Hussong et al., 1987; Jones et al., 1991 ; Nilsson et al., 1991; Roszak et al., 1984; Saha et al., 1991), most of these publications do not include quantitative data and are not suitable for the assessment of the significance of the VBNC state (Barer $e t$ al., 1993; Weichart et al., 1992).

One of the most well-described cases of VBNC cell formation is that of the estuarine human pathogen $V$ ibrio vulnificus (Oliver, 1993; Oliver et al., 1991). The organism grows on a multitude of carbon sources and survives well at temperatures between 14 and $43{ }^{\circ} \mathrm{C}$ at a wide range of salinities and nutrient concentrations (Kaspar \& Tamplin, 1993). Culturability of $V$. vulnificus is maintained during several months of starvation at temperatures within the range conducive for growth. During cold exposure, i.e. at temperatures around $5^{\circ} \mathrm{C}$, however, the organism cannot maintain culturability for longer than a few days or weeks. Thus, VBNC cells are formed in response to low temperature exposure rather than starvation. The growth phase prior to cold incubation has been identified as the major determinant for maintenance of culturability at low temperatures (Oliver et al., 1991). Recently, resuscitation of a fraction of VBNC cells has been observed in membrane chambers in situ in the estuarine environment (Oliver et al., 1995) and in vivo in mice (Oliver \& Bockian, 1995). Thus it appears that certain specific conditions might allow recovery of VBNC cells of the organism. It remains to be elucidated, however, how this recovery is brought about, and whether the recovery potential is maintained in a fraction of the population for extended periods, or whether it is merely a transient feature of cells which undergo irreversible loss of growth capability. Therefore it remains to be established what function VBNC cells might play in the environment, for instance as a phase in the life cycle dedicated to dispersal or long term persistence.

To this end, we have investigated the persistence and resuscitation potential of VBNC $V$. vulnificus in detail with several quantitative approaches. The results presented in this paper indicate that VBNC cells of the organism display increased stability after extended cold incubation, and that this resistance is in fact comparable to that of cells starved at growth temperature. The different techniques applied for the detection of resuscitation allow the population of VBNC cells to be dissected into injured and non-recoverable cells.

\section{METHODS}

Bacterial strains and growth conditions. In this study, two colony variants of $V$. vulnificus strain $C 7184$ were employed: the translucent $(\mathrm{T})$ and the opaque $(\mathrm{O})$ variants as described by Simpson et al. (1987). C7184T is a spontaneously derived isogenic translucent and non-virulent mutant of the encap- sulated (opaque) strain C7184O. All experiments were performed at least in triplicate with the translucent variant, and in all studies at least one set of experiments with the opaque variant was included to test whether the two strains differed in their behaviour. The organisms were grown in VNSS or VNSS/2 medium at $24{ }^{\circ} \mathrm{C}$ with shaking. The medium VNSS [salinity corresponding to $2.5 \%(\mathrm{w} / \mathrm{v}) \mathrm{NaCl}$ contained the salt concentrations as described by Nyström et al. (1986) and designated 'NSS salts': per 1 distilled water, $17.6 \mathrm{~g} \mathrm{NaCl}, 1.47 \mathrm{~g} \mathrm{Na}_{2} \mathrm{SO}_{4}$, $0.08 \mathrm{~g} \mathrm{NaHCO}_{3}, 0.25 \mathrm{~g} \mathrm{KCl}, 0.04 \mathrm{~g} \mathrm{KBr}, 1.87 \mathrm{~g} \mathrm{MgCl}_{2} .6 \mathrm{H}_{2} \mathrm{O}$, $0.41 \mathrm{~g} \mathrm{CaCl}_{2} .2 \mathrm{H}_{2} \mathrm{O}, 0.008 \mathrm{~g} \mathrm{SrCl}_{2}$ and $0.008 \mathrm{~g} \mathrm{H}_{3} \mathrm{BO}_{3}$. The medium VNSS $/ 2$ contained half the concentrations of these salts, and thus represented a medium of estuarine salinity corresponding to roughly $1.3 \% \mathrm{NaCl}$. Both media contained identical concentrations of the following nutrients, which were added separately after sterilization: peptone, yeast extract, glucose and $\mathrm{Na}_{2} \mathrm{HPO}_{4}$ [final concentrations $\left(\mathrm{g} \mathrm{l}^{-1}\right) 1 \cdot 0,0 \cdot 5,0 \cdot 5$ and $0 \cdot 01$, respectively] were added from a $10 \times$ stock solution which was autoclaved separately, and $\mathrm{FeSO}_{4} .7 \mathrm{H}_{2} \mathrm{O}$ was added to a final concentration of $0.01 \mathrm{mM}$ from a filter-sterilized $100 \times$ stock solution containing $0.4 \mathrm{M}$ tricine ( $\mathrm{pH} \mathrm{7.8)}$ to maintain the iron in a solubilized and thus utilizable form. These media were shown to give almost identical growth rates of the two strains. Luria broth (LB) media contained 15 (LB15), or 20 (LB20) g $\mathrm{NaCl} l^{-1}$.

Starvation protocol. As starvation media, a MOPS-buffered system, modified from Neidhardt $e t$ al. (1974) as described by Ostling et al. (1991), was used. In agreement with the growth media reported in the preceding section, two different formulations were used for starvation exposure, again only differing in the salt content: $3 \mathrm{M}$-all contained NSS salts as in VNSS, whereas $2 \mathrm{M}$-all contained salts as in VNSS $/ 2$. Both contained final concentrations of $40 \mathrm{mM}$ MOPS ( $\mathrm{pH} \mathrm{8.2)} \mathrm{and} 4 \mathrm{mM}$ tricine ( $\mathrm{pH} 7.8$ ) with $0.01 \mathrm{mM} \mathrm{FeSO}_{4} \cdot 7 \mathrm{H}_{2} \mathrm{O}$, added from filtersterilized stock solutions. This starvation medium does not contain a utilizable carbon, nitrogen or phosphorus source and hence provides multiple starvation conditions.

After growth in VNSS or VNSS $/ 2$ at $24^{\circ} \mathrm{C}$ on a rotary shaker, an overnight culture was diluted in fresh growth medium at a ratio of $1: 100$, and incubated for another $4-5 \mathrm{~h}$ under identical conditions until an $\mathrm{OD}_{610}$ of 0.15 was reached. The cells were harvested at $12000 \mathrm{~g}$ and $15^{\circ} \mathrm{C}$ for $10 \mathrm{~min}$ (Sorvall RC5Bplus centrifuge; SS34 rotor), washed once in the appropriate starvation medium ( $3 \mathrm{M}$-all or $2 \mathrm{M}$-all), and then resuspended and diluted 1:50 in the starvation medium, giving a cell density of $1-3 \times 10^{6}$ c.f.u. $\mathrm{ml}^{-1}$. These suspensions were then held without shaking at $24^{\circ} \mathrm{C}$ ('starved') or at $5{ }^{\circ} \mathrm{C}$ ("coldincubated'). The latter but not the former condition leads to VBNC formation in V. vulnificus. Plate counts were performed every $2-3 \mathrm{~d}$.

Stress treatments. Ethanol exposure was performed with $10-15 \%(\mathrm{v} / \mathrm{v})$ ethanol $(\mathrm{BDH}, 97-100 \%)$ at $24{ }^{\circ} \mathrm{C}$, and oxidative stress treatment was achieved by the addition of $3 \mathrm{mM} \mathrm{H}_{2} \mathrm{O}_{2}$ [from $30 \%(\mathrm{v} / \mathrm{v})$ stock, M\&B Pronalys] at $24{ }^{\circ} \mathrm{C}$. In both assays, the treated cells were held in closed $1.5 \mathrm{ml}$ Eppendorf tubes during exposure. In order to remove reactive $\mathrm{H}_{2} \mathrm{O}_{2}$ in the oxidative stress treatment at the time of sampling, subsamples were treated with 2600 units catalase $\mathrm{ml}^{-1}$ (Sigma) for $5 \mathrm{~min}$ before plating. Sonication of cell suspensions was carried out with a Branson 450 sonicator with a $12 \mathrm{~mm}$ wide tip. Samples $(35 \mathrm{ml})$ of suspension were placed into $50 \mathrm{ml}$ Falcon polycarbonate tubes, and the sonication tip was submerged $0.7-0.8 \mathrm{~mm}$ into the suspension. The samples were kept on ice during sonication and the sonicator settings were level 9 (of 10) at $50 \%$ duty cycle. After 15 pulses of $0.5 \mathrm{~s}$, the samples were left on ice for $60 \mathrm{~s}$ before sonication was continued, in order to 
avoid heating of the samples. Subsamples $(2.5 \mathrm{ml})$ were withdrawn at regular intervals $(0,15,30,45,60 \mathrm{sec}$ etc. $)$ and fixed with $2 \%(\mathrm{v} / \mathrm{v})$ formaldehyde within $5 \mathrm{~min}$ of sampling. Survival after oxidative stress was assessed by c.f.u. counts, and survival after sonication by c.f.u. counts and microscopic observation.

Plate counts. As standard plating media, VNSS or VNSS/2 agar plates were prepared by autoclaving the whole formulation given above, including salts and nutrients, together with $0.01 \mathrm{~g}$ $\mathrm{FeSO}_{4} \cdot 7 \mathrm{H}_{2} \mathrm{O} \mathrm{l}^{-1}$ and $16 \mathrm{~g}$ Bacteriological Agar No. $1 \mathrm{l}^{-1}$ (Oxoid). Cell samples were diluted in the appropriate starvation medium (3M-all or $2 \mathrm{M}$-all), 6-8 subsamples $(10 \mu \mathrm{l})$ of each dilution were placed on the appropriate plates (VNSS or VNSS/2) and c.f.u. counts determined after incubation (the socalled 'drop plate method' (Hoben \& Somasegaran, 1982). Samples of starved and cold-incubated cultures of $V$. vulnificus were placed on VNSS plates and incubated at various temperatures $\left(5,15,24\right.$ and $\left.37^{\circ} \mathrm{C}\right)$. No growth was observed at $5{ }^{\circ} \mathrm{C}$ even after incubation for more than 3 months. The two higher temperatures $\left(24\right.$ and $\left.37^{\circ} \mathrm{C}\right)$ gave identical counts, while lower counts were observed at $15^{\circ} \mathrm{C}$, even after 4 weeks of incubation (data not shown). Thus, $24^{\circ} \mathrm{C}$ was chosen as the standard incubation temperature throughout this study. Plates were incubated for $40 \mathrm{~h}$ at $24^{\circ} \mathrm{C}$, and the development of additional colonies was assessed during another $2-5 \mathrm{~d}$ at $24^{\circ} \mathrm{C}$. No increase in colony numbers was observed after prolonged incubation of plates in any of the experiments.

Soft agar plates were prepared with the salt and nutrient composition of VNSS or VNSS/2, but with $1 / 2,1 / 4$ or $1 / 8$ of the agar content, i.e. 8,4 or 2 g Bacteriological Agar No. $11^{-1}$, or, alternatively, with the identical concentration of agarose (Sigma Type I-A: low EEO, No. A-0169).

Microcolony assays. Coverslip microcolony assays were performed according to Fry \& Zia (1982). Slides were coated with $0.5 \mathrm{ml}$ VNSS or VNSS $/ 2$ containing $0.8 \mathrm{~g}$ agar or agarose $1^{-1}$. Samples $(10 \mu \mathrm{l})$ were placed on the freshly set agar, covered with a coverslip and incubated in a moist chamber at 24 or $37^{\circ} \mathrm{C}$. The slide cultures were inspected daily over a $10 \mathrm{~d}$ period at a magnification of $1000 \times$ by phase-contrast microscopy with an Olympus BH-2 microscope.

Most probable number recovery experiments. Large-scale most probable number (MPN) experiments with incubation periods of several weeks were performed in order to determine the potential for recovery of VBNC cells in different liquid laboratory media. For this purpose, samples of the coldincubated suspensions were diluted in cold $3 \mathrm{M}$-all or $2 \mathrm{M}$-all and MPN assays were performed as described below. As growth media in the MPN assay, LB15, VNSS, or VNSS/2 were used. In some experiments VNSS and VNSS $/ 2$ were diluted with $10 \times$ volumes of NSS or NSS/2, respectively, to achieve a medium with lower nutrient content designated as $0.1 \mathrm{VNSS}$ or $0 \cdot 1 \mathrm{VNSS} / 2$, respectively. To test the effects of cell-free supernatants on recovery, $0 \cdot 1 \mathrm{VNSS}$ was mixed $1: 1$ with supernatants from starved cultures of the organism. Supernatants were obtained from cells starved for $23 \mathrm{~d}$ in NSS by centrifugation at $12000 \mathrm{~g}$ (SS34, Sorvall RC5Bplus) for $30 \mathrm{~min}$ at $15^{\circ} \mathrm{C}$. The supernatants were filter-sterilized twice using $0.2 \mu \mathrm{m}$ pore size MFS cellulose acetate filters before addition to the growth medium, and the resulting medium was designated $0 \cdot 1$ Super.

Volumes of $2.5 \mathrm{ml}$ growth medium were dispensed into polypropylene tubes (total volume $15 \mathrm{ml}$ ), and sets of $30-60$ tubes of each medium were inoculated with $10 \mu$ l of the dilutions in order to achieve a statistically reliable MPN estimate. Positive controls with identical media inoculated with dilutions of starved cultures (culturable cells), and three negative controls without inoculum were included in every set of media. The tubes were incubated at $24^{\circ} \mathrm{C}$ with shaking for $16-70 \mathrm{~d}$. Turbidity was recorded daily during the first 5 days, then at regular intervals of $2-3 \mathrm{~d}$. Tubes which did not display any turbidity after $16 \mathrm{~d}$ were plated on VNSS and VNSS $/ 2$ plates to allow for the possibility of low growth yields in certain media, especially those with low carbon content such as NSS or diluted media $(0 \cdot 1 \mathrm{VNSS}, 0 \cdot 1$ Super). MPN estimates were calculated from the negative natural logarithm of the fraction of sterile tubes.

In order to be able to compare the culturability on plates with that in MPN assays using liquid media, the recovery experiments were initiated at a time when the plate counts were in the range of $10-1000$ c.f.u. $\mathrm{ml}^{-1}$, which is after $1-2$ weeks of cold incubation. Compared to experiments commencing after longer exposure when less than 10 c.f.u. $\mathrm{ml}^{-1}$ can be detected, these counts can still be determined in a reliable quantitative fashion. This allowed accurate assessment of the population at a time when more than $99.5 \%$ of the cells were nonculturable, so that any potential resuscitation could easily be detected.

Microscopic counts. After fixation with $2 \%$ formaldehyde, cells were stained with $0.5 \mu \mathrm{g}$ DAPI (4',6-diamidino-2-phenylindole) $\mathrm{ml}^{-1}$, the suspensions filtered onto $0.22 \mu \mathrm{m}$ pore size prestained black filters (Nucleopore) and counted with an Olympus $\mathrm{BH} 2$ microscope fitted with an epifluorescence $\mathrm{BH} 2$ - RFCA analyser with a BH2-DMU cube (excitation wavelength $365 \mathrm{~nm}$ ) and a 20L435-W22 supplementary barrier filter $(456 \mathrm{~nm})$. A minimum of 500 cells in more than 5 fields of vision, or, in the case of low counts, at least 50 fields of vision were counted. In several instances, the DNA content of the cells fixed with formaldehyde was confirmed by staining with $0.01 \%$ Acridine Orange (Sigma) or with $50 \mu \mathrm{g}$ ethidium bromide $\mathrm{ml}^{-1}$ (Williamson \& Palframan, 1989).

\section{RESULTS}

\section{Stress resistance of growing and starved cells}

Cells of $V$. vulnificus starved at $24^{\circ} \mathrm{C}$ displayed an increased resistance to ethanol stress at concentrations of 10,12 or $15 \%$. The plate count data of $V$. vulnificus C7184T treated with $10 \%$ ethanol are shown in Fig. 1. Cells starved for 94

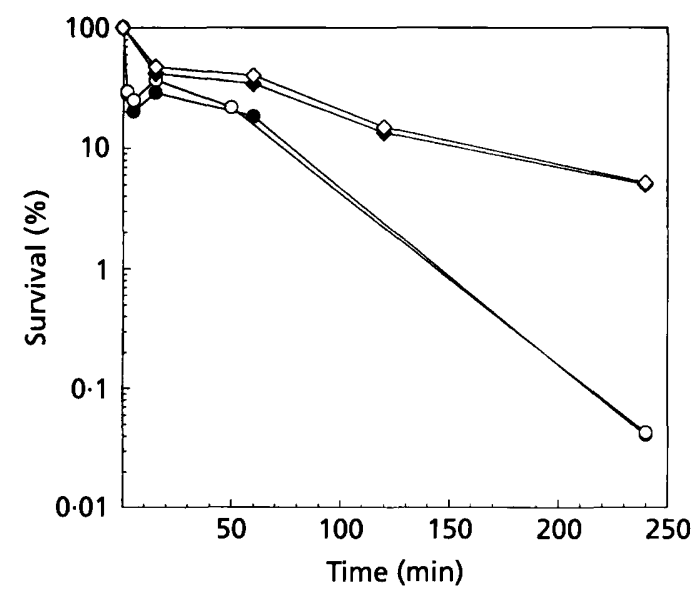

Fig. 1. Survival of growing and starved $V$. vulnificus C7184T during challenge with $10 \%$ ethanol at $24^{\circ} \mathrm{C}$ as assessed by c.f.u. counts. Cells were grown in either VNSS (O) or LB20 (O), or starved in $3 \mathrm{M}$-all at $24^{\circ} \mathrm{C}$ for $94 \mathrm{~d}(\diamond)$ or $122 \mathrm{~d}(\diamond)$ prior to ethanol treatment. Data are means of two independent experiments. 


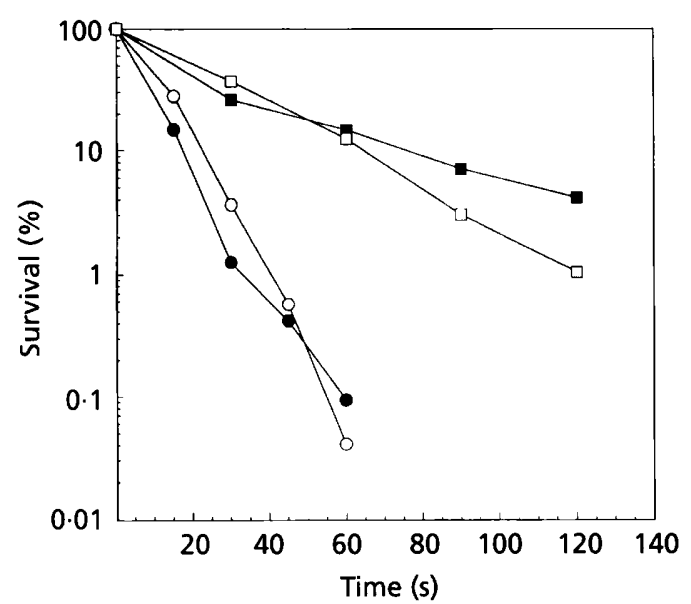

Fig. 2. Survival of growing and starved $V$. vulnificus C7184T during sonication as assessed by c.f.u. counts and microscopic counts of DAPI-stained suspensions. Cells were grown in VNSS/2 $(O, \theta)$ or starved at $24^{\circ} \mathrm{C}$ for 1 or $5 \mathrm{~d}$ in $2 \mathrm{M}$-all $(\square, \square)$ prior to sonication. C.f.u. counts $(O, \square)$ and microscopic counts of DAPI-stained cells $(0, \square)$ were performed as described in the Methods section. All data are means of duplicates.

and $110 \mathrm{~d}$ displayed $5 \%$ survival after 240 min treatment with $10 \%$ ethanol, while growing cells showed only $0.04 \%$ survival. After exposure to 12 or $15 \%$ ethanol, a significant but slightly less pronounced difference between the resistance of growing and starved cells was observed (data not shown).

The resistance of starved cells towards oxidative stress closely resembled the resistance of growing cells under the conditions tested $\left(3 \mathrm{mM} \mathrm{H} \mathrm{H}_{2} \mathrm{O}_{2}\right.$ at $\left.24{ }^{\circ} \mathrm{C}\right)$ : growing cells of $\mathrm{C} 7184 \mathrm{~T}$ and $\mathrm{C} 7184 \mathrm{O}$ retained 0.08 and $2.0 \%$, respectively, of the initial c.f.u. count after $20 \mathrm{~min}$ treatment with $3 \mathrm{mM} \mathrm{H}_{2} \mathrm{O}_{2}$ (means of four experiments), whereas cells starved in $2 \mathrm{M}$-all for $2 \mathrm{~d}$ at $24^{\circ} \mathrm{C}$ displayed 0.05 and $0.43 \%$ of the initial culturable count, respectively, after the same treatments.

\section{Mechanical stress resistance of growing, starved and VBNC cells}

Growing, starved and VBNC cells of C7184T and C7184O were subjected to sonication as a means of determining the mechanical stability of the cells. Plate counts and microscopic counts of DAPI-stained cells were used to assess the integrity of cells before and after treatment. Essentially, the same numbers were obtained with plate counts and DAPI counts of sonicated cells (Fig. 2) in both growing and starving cultures, indicating that the microscopic counts were a reliable estimate of stability.

Cells of $V$. vulnificus $\mathrm{C} 7184 \mathrm{~T}$ starved for 1 or $5 \mathrm{~d}$ at $24{ }^{\circ} \mathrm{C}$ displayed a higher resistance towards sonication than did growing cells. The decimal reduction time was $19 \mathrm{~s}$ for growing cells (as assessed by both plate and DAPI counts), compared to $63 \mathrm{~s}$ (plate counts) and $80 \mathrm{~s}$ (DAPI counts)

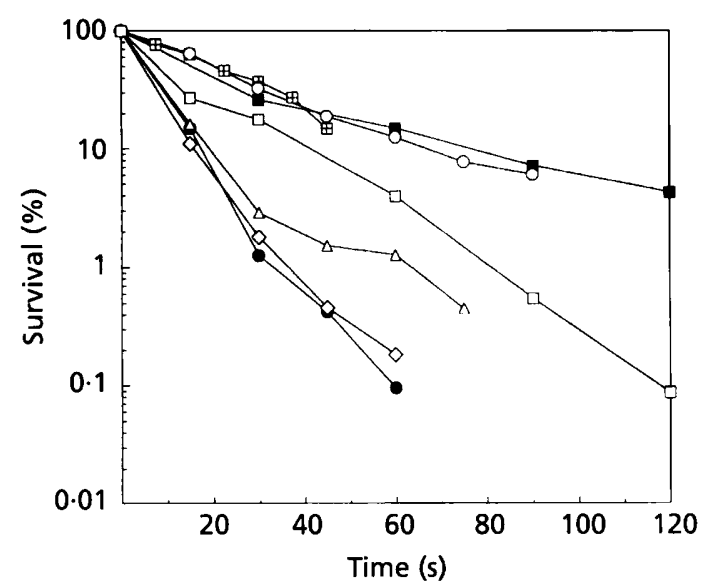

Fig. 3. Stability of growing, starved and VBNC cells of $V$. vulnificus $\mathrm{C7184T}$ during sonication as assessed by microscopic counts of DAPI-stained cells. The data for growing $(0)$ and starved $(\square)$ cells are identical with the microscopic count data shown in Fig. 2. VBNC cells were assessed with regard to their resistance to identical sonication treatments after incubation at $5^{\circ} \mathrm{C}$ for $2(\diamond), 4(\triangle), 6.5(\square), 9(\boxplus)$ and $16(\bigcirc)$ weeks. The data for cells after 2 and 9 weeks of cold incubation are means of triplicates, and those for 16-week-old cells are means of duplicates. Results for 4- and 6.5-week-old cells are derived from single sets of data.

for starved cells. Cells incubated at $5^{\circ} \mathrm{C}$, and thus transformed into the VBNC state, displayed sonication resistance (as assessed by microscopic counts) closely resembling that of growing cells during the first 6 weeks of cold incubation. After 6 weeks, however, a significant increase in the resistance displayed by VBNC cells was observed, which further increased after 9 weeks, and then stabilized at that level for at least another 7 weeks (Fig. 3). The final degree of resistance of VBNC cells was indistinguishable from that of starved cells. Microscopy did not indicate any major change in the shape of the cells, but they appeared to become slightly smaller throughout the starvation and cold incubation period. These results were obtained from three independent experiments with $\mathrm{C} 7184 \mathrm{~T}$ (twice with $2 \mathrm{M}$, once with $3 \mathrm{M}$ ), and also from a series of experiments with $\mathrm{C} 7184 \mathrm{O}$ (in $2 \mathrm{M}$ ). No significant differences between the media or strains could be detected.

To determine the susceptibility of VBNC cells to spontaneous lysis at elevated temperature, suspensions of $\mathrm{C} 7184 \mathrm{~T}$ which had been incubated at $5{ }^{\circ} \mathrm{C}$ for 77 and $111 \mathrm{~d}$, were transferred to $24^{\circ} \mathrm{C}$ and the DAPI counts monitored. In the first experiment, the total DAPI counts decreased to $57 \%$ of the initial count after $8 \mathrm{~d}$ at $24^{\circ} \mathrm{C}$. In the second experiment lysis proceeded in an exponential fashion with a decimal reduction time of $36.5 \mathrm{~d}$ throughout $95 \mathrm{~d}$ of observation. Thus after $73 \mathrm{~d}, 1 \%$ of the initial DAPI count was still detected. Both sets of data are means of duplicates, one of which was held in $2 \mathrm{M}$-all and the other in $3 \mathrm{M}$-all, with no significant difference between the two conditions. During the time of observation, no c.f.u. counts indicative of resuscitation or contamination of the samples were seen in either of the experiments. 
Table 1. Recovery of $V$. vulnificus C7184T on plates with different agar content

\begin{tabular}{|c|c|c|c|c|c|}
\hline \multirow{2}{*}{$\begin{array}{c}\text { Agar } \\
\text { content } \\
(\%, w / v)\end{array}$} & \multicolumn{5}{|c|}{ Recovery (c.f.u. $\mathrm{ml}^{-1}$ ) } \\
\hline & $\begin{array}{l}\text { Exponentially } \\
\text { growing cells, } \\
\qquad 24^{\circ} \mathrm{C}\end{array}$ & $5 \mathrm{~d}, 5^{\circ} \mathrm{C}^{*}$ & $7 \mathrm{~d}, 5^{\circ} \mathrm{C}^{*}$ & $7 \mathrm{~d}, 5^{\circ} \mathrm{C} \dagger$ & $17 \mathrm{~d}, 5^{\circ} \mathrm{C} \ddagger$ \\
\hline $1 \cdot 6$ & $1.70 \times 10^{6}$ & $5.9 \times 10^{3}$ & $1 \cdot 2 \times 10^{3}$ & $7 \cdot 4 \times 10^{2}$ & $1.66 \times 10^{4}\left(4.4 \times 10^{3}\right)$ \\
\hline $0 \cdot 8$ & $1 \cdot 72 \times 10^{6}$ & $6.1 \times 10^{3}$ & $1.45 \times 10^{3}$ & $9.7 \times 10^{2}$ & $1.77 \times 10^{4}\left(5.83 \times 10^{3}\right)$ \\
\hline $0 \cdot 4$ & $1.68 \times 10^{6}$ & $6.8 \times 10^{3}$ & $9 \cdot 2 \times 10^{3}$ & $1.44 \times 10^{3}$ & $1.77 \times 10^{4}\left(3.08 \times 10^{3}\right)$ \\
\hline
\end{tabular}

* A suspension with an initial count of $2 \cdot 19 \times 10^{6}$ c.f.u. $\mathrm{ml}^{-1}$ was incubated at $5^{\circ} \mathrm{C}$ for 5 or $7 \mathrm{~d}$ prior to recovery.

†A suspension with an initial count of $1 \cdot 49 \times 10^{6}$ c.f.u. $\mathrm{ml}^{-1}$ was incubated at $5^{\circ} \mathrm{C}$ for $7 \mathrm{~d}$ prior to recovery.

$\ddagger$ A set of three independent parallel samples were derived from a suspension with an initial count of $1.7 \times 10^{6}$ c.f.u. $\mathrm{ml}^{-1}$. The samples were starved for $25 \mathrm{~h}$ and then incubated at $5{ }^{\circ} \mathrm{C}$ for $17 \mathrm{~d}$ prior to recovery. Means of counts of the three samples are shown, with SD in parentheses.

\section{Recovery and growth of cold-incubated cells on agar plates}

Exponentially growing cells of $V$. vulnificus gave rise to the same c.f.u. counts independent of the agar content of the plating medium (Table 1, column 2). When identical samples from a dilution of cold-incubated suspensions of $V$. vulnificus were placed on VNSS agar plates with different agar (or agarose) content, the agar content of the plates appeared to modulate the growth ability of a variable fraction of the cold-incubated population (Table 1): a lower agar content increased the culturability by as much as eightfold. When a whole range of agar concentrations $(1 \cdot 6,0 \cdot 8,0 \cdot 6,0 \cdot 5,0 \cdot 4,0 \cdot 3,0 \cdot 2 \%, \mathrm{w} / \mathrm{v})$ was tested, the optimal culturability was achieved with $0.4 \%$ agar, which is $1 / 4$ of the commonly used concentration of $1 \cdot 6 \%$. Lower agar contents $(0.3$ and $0.2 \%)$ did not allow colony formation due to extensive swimming (data not shown). The improved recovery on soft agar plates, however, was only pronounced in certain experiments and only during a certain period of cold exposure (see Table 1). In most instances, c.f.u. counts on soft agar plates did not exceed those on ordinary plates by more than a factor of $1 \cdot 1-1 \cdot 2$. Cells which had been subjected to cold exposure immediately after washing (Table 1, columns 3-5) showed the same recovery pattern as cells that had been starved at $24{ }^{\circ} \mathrm{C}$ before cold incubation (Table 1, column 6). In no instance did soft agar plates allow for growth of a major fraction of the whole VBNC population. The use of agarose instead of agar had no significant effect on recovery (data not shown).

\section{Microcolony assays}

Microcolony assays performed according to Fry \& Zia (1982) yielded colony growth of culturable cells (starved cells which had been held at $24^{\circ} \mathrm{C}$ ) but not from nonculturable cells. Using the culturable cells as control, the number of colonies counted on the slides corresponded with the plate counts (data not shown), indicating that the microcolony assay provides optimal conditions

\section{Table 2. Recovery of $V$. vulnificus C7184T}

MPN and c.f.u. of recoverable cells were determined after incubation for $8 \mathrm{~d}$ at $5{ }^{\circ} \mathrm{C}$. Recovery is presented as a percentage of the initial count prior to cold incubation $\left(1.49 \times 10^{6}\right.$ c.f.u. $\left.\mathrm{ml}^{-1}\right)$. Assays and media are described in the Methods section. ND, Not determined.

\begin{tabular}{|lll|}
\hline Medium & \multicolumn{2}{c|}{ Recovery (\% initial c.f.u.) } \\
\cline { 2 - 3 } & MPN & C.f.u. \\
\hline VNSS & $0 \cdot 24$ & $0 \cdot 29$ \\
LB15 & $0 \cdot 12$ & $0 \cdot 10$ \\
$0 \cdot 1$ VNSS & $0 \cdot 31$ & ND \\
$0 \cdot 1$ Super & $0 \cdot 27$ & ND \\
NSS & $0 \cdot 17$ & ND \\
\hline
\end{tabular}

for growth, and does not give an underestimation of culturability. While culturable cells gave rise to small colonies within $8 \mathrm{~h}$ and large colonies after $24 \mathrm{~h}$, the nonculturable cells did not yield any microcolonies, as viewed by phase-contrast microscopy, within $9 \mathrm{~d}$. VBNC cells could in fact be observed to retain their morphology without detectable change throughout the incubation period. This result was obtained with cultures of both the translucent and the opaque strain, employing either VNSS or VNSS/2 as growth media and $3 \mathrm{M}$-all or $2 \mathrm{M}$-all as incubation media, and incubating the slides at either $24^{\circ} \mathrm{C}$ or $37^{\circ} \mathrm{C}$. The same results were observed with either agar or agarose as gelating agent, eliminating the possibility that impurities in the agat might prevent or inhibit growth of the organism.

\section{MPN recovery experiments}

The data from a representative MPN recovery experiment involving the translucent strain C7184T is shown in Table 2. The extent of recovery in MPN assays during $16 \mathrm{~d}$ was identical to that on agar plates prepared from the 
corresponding media. Thus resuscitation of VBNC cells could not be detected in the liquid media tested, while culturable cells gave rise to visible growth in all media within $3 \mathrm{~d}$. This was shown in five independent experiments involving the translucent colony variant C7184T. In one experiment involving the opaque strain $\mathrm{C} 7134 \mathrm{O}$, after $13 \mathrm{~d}$ at $5{ }^{\circ} \mathrm{C}$ (in $2 \mathrm{M}$-all) a fraction of $1.3 \times 10^{-3} \%$ of the initial c.f.u. was recovered on agar plates, while recovery in MPN assays was $8 \times 10^{-4} \%$ (VNSS/2) and $3 \times 10^{-4} \%(0 \cdot 1 \mathrm{VNSS} / 2)$. Resuscitation was undetectable even when incubation was allowed to proceed for a total of more than $35 \mathrm{~d}$ in three experiments, one involving the opaque strain and two with the translucent strain. In both plate counts and MPN assays, VNSS-based media gave the highest recovery of cold-incubated cells, whereas LBbased media gave only $35-50 \%$ of those counts (Table 2 ). Diluted growth medium ( $0 \cdot 1 \mathrm{VNSS})$, or diluted medium with added supernatants of starved cultures ( 0.1 Super), did not allow significantly improved recovery. When nutrient-free salt solution (NSS) was used as recovery medium, slow but significant growth of culturable cells could be observed, but the MPN estimate indicated recovery of a fraction smaller than that in the other media (Table 2). Supernatants of growing cells and of VBNC cells of the organism which had been obtained in the same way as described for supernatants of starved cells were also tested in small scale MPN assays employing 3-5 tubes per dilution and medium; these additions, however, did not improve recovery (data not shown). Further, the addition of growth factors, such as a mixture of eight vitamins (as described by Terleckyj et al., 1975), a mixture of nucleotides $\left(10 \mu \mathrm{g}\right.$ guanine, adenine and uracil ml $\mathrm{ml}^{-1}$ ), or $2 \mathrm{mg}$ sodium citrate, oxaloacetic acid, sodium lactate, or succinic acid $\mathrm{ml}^{-1}$ (as described by Heinmets et al. (1954), permitted growth of the same fraction of the population as the unamended medium in small-scale MPN assays involving three tubes per dilution and medium (data not shown). Thus, none of the modifications of the media tested gave improved recovery of cold-incubated populations of either of the two strains of $V$. vulnificus.

\section{DISCUSSION}

Formation of VBNC cells has been reported for a large number of bacterial species, but the role which these cells might play in the environment and in pathogenesis has so far not been resolved (Barer et al., 1993; Oliver, 1993; Roszak \& Colwell, 1987). While it has repeatedly been shown that growing bacterial populations can be transformed into populations containing large proportions of VBNC cells (Oliver, 1993), the questions of whether these cells can persist, and whether and under which conditions subpopulations of such cells can recover has not been addressed in detail. The bacterium $V$. vulnificus offers a suitable model system in that it forms populations of VBNC cells at temperatures well below the minimum growth temperature, and, by precluding the possibility of cryptic growth in VBNC populations while kept at low temperature, it is feasible to exactly determine the age of the VBNC cells. Furthermore, the organism displays formation of populations consisting entirely of VBNC cells, if the transformation is allowed to proceed for a sufficient period of time. In the work described in this paper, we attempted to estimate the persistence potential of low-temperature-induced VBNC cells of $V$. vulnificus, and studied their recovery potential in quantitative assays under controlled laboratory conditions.

\section{Stress resistance of starved and VBNC $\boldsymbol{V}$. vulnificus}

Several bacterial species have been shown to mount increased resistance against an array of stressful conditions when starved for certain essential nutrients (Givskov et al., 1994; Hartke et al., 1994; Jenkins et al., 1988, 1990; Jouper-Jaan et al., 1992; Nyström et al., 1992), an effect termed 'cross-protection by starvation'. In an earlier paper involving $V$. vulnificus, it was shown that such cross-protection is mounted against cold exposure in this organism (Oliver et al., 1991). Here, we present data indicating that $V$. vulnificus is indeed protected significantly against some stresses when starved for a few days at temperatures within the range conducive for growth. However, while the cross-protective effect of starvation against ethanol exposure is significant (Fig. 1), crossprotection against oxidative stress (as exerted by $\mathrm{H}_{2} \mathrm{O}_{2}$ ) could not be detected. Moreover, preliminary experiments with heat shock exposure at $57^{\circ} \mathrm{C}$ indicate that crossprotection against heat stress does not occur (data not shown). These findings might indicate differences between the phenotype of starved cells of $V$. vulnificus and those of other bacteria, which have generally been shown to display strong cross-protection against both oxidative and heat stress (Givskov et al., 1994; McCann et al., 1991; Nyström et al., 1992).

The effect of mechanical stress, or more accurately shear stress, exerted by sonication is easily and reliably assessed by microscopy following DAPI staining, as shown by the close match of c.f.u. counts and microscopic counts in Fig. 2. (In fact, culturability of sonicated cells decreases slightly faster than the microscopic counts, which might be expected as cells subjected to mechanical stress might lose viability before they visibly lose their integrity.) Thus, sonication survival as assayed by DAPI microscopy is a valuable tool for studying stress survival of culturable cells as well as nonculturable cells. To our knowledge it is the only such assay currently available for this purpose, since other stresses are impossible to assess with regard to their effect on nonculturable cells due to the difficulty in reliably determining viability. At present, culturability is the only sufficient criterion for viability available. None of the other viability assays described in the literature (Diaper \& Edwards, 1994; Dufour \& Colon, 1992; Kaprelyants \& Kell, 1992; Kogure et al., 1979; Rodriguez et al., 1992; Zimmermann et al., 1978) can be considered to assess a necessary or a sufficient criterion for cell viability. Cell integrity and stability, and staining by DAPI as an indication of DNA content, do however constitute necessary viability criteria.

In this study we show that the sonication resistance of starved cells is markedly increased compared to cells 
growing at the same temperature, and that VBNC cells initially display sonication resistance similar to that of growing cells, but acquire, after several weeks of cold incubation, a final stability which resembles the resistance of starving cells. In addition, the VBNC cells kept at low temperature for several months display stability against spontaneous lysis even after transfer to room temperature. It is possible that our observations concerning the stability of VBNC cells might partly be related to the changes in membrane fatty acid composition reported for the same organism (Linder \& Oliver, 1989). Further, modulations of the cell wall composition depending on the growth phase have been reported in other bacteria (Buchanan \& Sowell, 1982; Leduc et al., 1989), and these might also be responsible for the changes in the overall stability of the cells (van der Linden et al., 1992). In a recent paper, VBNC cells of Vibrio cholerae have been reported to display a thicker and more electron-dense peptidoglycan layer than growing cells (Kondo et al., 1994).

\section{Recovery of VBNC bacteria}

In most studies of resuscitation of VBNC cells reported in the literature (Allen-Austin et al., 1984; Grimes \& Colwell, 1986; Hussong et al., 1987; Jones et al., 1991; Nilsson et al., 1991; Roszak et al., 1984; Saha et al., 1991), the quantitative details of recovery and growth have not been assessed, and thus it remains unclear how many cells actually resuscitate and whether the 'resuscitation' seen is due to growth of a low number of either genuinely culturable or resuscitated cells (Barer et al., 1993; Husevåg, 1995; Morgan et al., 1991; Ravel et al., 1995; Rose et al., 1990; Weichart et al., 1992). The only reliable way to determine the fraction of the population capable of resuscitation, besides advanced microscopic detection methods (Lewis et al., 1994) and flow cytometry, is the application of the MPN method, which is also called dilution extinction or fraction-negative method. In this type of assay the population is dissected in multiple samples of dilutions containing ultimately one or less than one cell per sample. This approach allows the recovery of single cells and their subsequent growth to be followed with high accuracy. It has been successfully employed in a study of Micrococcus luteus (Kaprelyants et al., 1994), which to our knowledge is the only publication to date that convincingly demonstrates resuscitation of a large proportion of VBNC populations. Recent reports on recovery of VBNC cells of $V$. vulnificus under in situ and in vivo conditions (Oliver \& Bockian, 1995; Oliver et al., 1995) have shed new light on this issue, and require the investigation of the details of recovery processes in this organism.

This study reports on the use of a variety of techniques, including MPN and microcolony assays, designed to detect resuscitation of VBNC cells of $V$. vulnificus which might occur in response to temperature and substrate upshift under laboratory conditions. For each of these approaches, we performed sets of experiments with both the translucent and the opaque colony variant of $V$. vulnificus in order to allow for the possibility that the two strains might behave differently. While recovery of coldincubated cells of $V$. vulnificus could be shown to be partly dependent on the nature of the substrates and on the conditions of recovery applied (Tables 1 and 2), resuscitation of VBNC cells generated under laboratory conditions was not observed. The possibility of substrateaccelerated death (Postgate \& Hunter, 1963) was excluded by showing that diluted or nutrient-free recovery media did not lead to improved recovery (Table 2), although growth of culturable cells of the organism was observed consistently in all media. Also, the addition of supernatants from starved, VBNC or growing cells had no effect on the recovery of cold-incubated populations in the laboratory media employed here (Table 2). Thus, we do not anticipate any mechanism of recovery analogous to the population effect reported for $M$. Iuteus (Kaprelyants $e t$ al., 1994; Votyakova et al., 1994). The addition of Krebs cycle intermediates, in addition to the primary carbon sources, had no stimulating effect on recovery of either the translucent or the opaque strain, and thus a dependence on those accessory substrates as reported in the literature (Heinmets $e t$ al., 1954) was not observed. A full selection of vitamins or nucleotides did not improve recovery of cold-incubated cells of the strains either, showing that the nonculturability observed is not due to the requirement for any of those growth factors.

Ultramicrocolony formation by nonculturable cells has been published for a strain of Pseudomonas fuorescens (Binnerup et al., 1993), as well as for natural samples (Fry \& Zia, 1982; Torrella \& Morita, 1981). The microcolony assays performed in our study showed, however, that VBNC cells of $V$. vulnificus are not capable of any, even limited, divisions under conditions conducive for growth of the organism. Incubation of microcolony and MPN assays for at least $10 \mathrm{~d}$ revealed no delayed recovery and outgrowth, as reported for Escherichia coli for example (Quesnel, 1963), under the conditions applied. Taken together, the results presented here rule out the possibility that resuscitation of VBNC cells of $V$. vulnificus could be triggered by either temperature shifts alone, as described earlier (Nilsson et al., 1991), or by the addition of standard nutrients or growth factors, or by the addition of culture supernatants, as was shown for $M$. luteus (Kaprelyants $e t$ al., 1994). Our results are in agreement with those obtained by flow cytometry by Firth et al. (1994), and confirm that resuscitation of nonculturable $V$. vulnificus does not readily occur under laboratory conditions. Our results with media of different nutrient and agar content indicate that, at least for limited periods during the transition to the VBNC state, there is a small proportion of the population which is 'injured' in the sense that it is only able to recover and regain growth ability if the conditions are optimal for growth. We suggest, however, that the majority of VBNC cells cannot be considered injured, as they are not able to grow under any, even nonselective and optimal, laboratory conditions. Further, we propose that injured subpopulations may partly explain the resuscitation of a fraction of the cold-incubated population reported in several instances (Nilsson et al., 1991; Oliver \& Bockian, 1995; Oliver et al., 1995). 


\section{Implications for survival}

The increased mechanical stability of aged VBNC cells reported here may give these cells a competitive advantage in their environment during extended exposure to low temperature. It can be speculated that the changes could allow for increased protection against, for example, predation or virus attack which have been found to control bacterial populations in aquatic ecosystems (Azam et al., 1983; Heldal \& Bratbak, 1991; Hennes \& Simon, 1995; Proctor et al., 1993). This is, to our knowledge, the first report indicating such a potential advantage of the VBNC state of a bacterium. In the light of the recent reports on the role and recovery of nonculturable Vibrio fischeri (Lee \& Ruby, 1995), on the resuscitation of VBNC M. luteus (Kaprelyants et al., 1994; Votyakova et al., 1994), and on resuscitation of VBNC $V$. vulnificus under natural and in vivo conditions (Oliver \& Bockian, 1995; Oliver $e t$ al., 1995) it can thus be reasoned that the VBNC state may indeed be a survival strategy for certain bacterial species. Even if in some cases the majority of VBNC cells are not capable of recovery under any condition, their stability could allow for persistence of their genetic information in the environment for longer periods than would be anticipated as deduced from the ability of these cells to grow, divide or form colonies.

\section{ACKNOWLEDGEMENTS}

This work was supported by grants from the Swedish National Environmental Protection Agency (EU-BIOTECHNOLOGY Program) and from the Australian Research Council.

\section{REFERENCES}

Allen-Austin, D., Austin, B. \& Colwell, R. R. (1984). Survival of Aeromonas salmonicida in river water. FEMS Microbiol Lett 21, 143-146.

Azam, F., Fenchel, T., Field, J. G., Gray, J. S., Meyer-Reil, L. A. \& Thingstad, F. (1983). The ecological role of water-column microbes in the sea. Mar Ecol Prog Ser 10, 257-263.

Barer, M. R., Gribbon, L. T., Harwood, C. R. \& Nwoguh, C. E. (1993). The viable but non-culturable hypothesis and medical microbiology. Rev Med Microbiol 4, 183-191.

Binnerup, S. J., Jensen, D. F., Thordal-Christensen, $H_{\text {. }}$ \& Soerensen, J. (1993). Detection of viable, but nonculturable Pseudomonas fuorescens DF57 in soil using a microcolony epifluorescence technique. FEMS Microbiol Ecol 12, 97-105.

Buchanan, C. E. \& Sowell, M. O. (1982). Synthesis of penicillinbinding protein 6 by stationary-phase Eschericbia coli. J Bacteriol 151, 491-494.

Colwell, R. R., Brayton, P. R., Grimes, D. J., Roszak, D. B., Huq, S. A. \& Palmer, L. M. (1985). Viable but nonculturable Vibrio cholerae and related pathogens in the environment: implications for release of genetically engineered microorganisms. Bio/Technology 3 , 817-820.

Diaper, J. P. \& Edwards, C. (1994). The use of fluorogenic esters to detect viable bacteria by flow cytometry. J Appl Bacteriol 77, 221-228.

Dufour, P. \& Colon, M. (1992). The tetrazolium reduction method for assessing the viability of individual bacterial cells in aquatic environments: improvements, performance and applications. Hydrobiologia 232, 211-218.
Firth, J. R., Diaper, J. P. \& Edwards, C. (1994). Survival and viability of Vibrio vulnificus in seawater monitored by flow cytometry. Lett Appl Microbiol 18, 268-271.

Fry, J. C. \& Zia, T. (1982). A method for estimating viability of aquatic bacteria by slide culture. J Appl Bacteriol 53, 189-198.

Givskov, M., Eberl, L., Møller, S., Kongsbak Poulsen, L. \& Molin, S. (1994). Responses to nutrient starvation in Pseudomonas putida KT2442: analysis of general cross-protection, cell shape, and macromolecular content. J Bacteriol 176, 7-14.

Grimes, D. J. \& Colwell, R. R. (1986). Viability and virulence of Eschericbia coli suspended by membrane chamber in semitropical ocean water. FEMS Microbiol Lett 34, 161-165.

Hartke, A., Bouche, S., Gansel, X., Boutibonnes, P. \& Auffray, Y. (1994). Starvation-induced stress resistance in Lactococcus lactis subsp. lactis IL1403. Appl Environ Microbiol 60, 3474-3478.

Heinmets, F., Taylor, W. W. \& Lehman, J. J. (1954). The use of metabolites in the restoration of the viability of heat and chemically inactivated Escherichia coli. J Bacteriol 67, 5-12.

Heldal, M. \& Bratbak, G. (1991). Production and decay of viruses in aquatic environments. Mar Ecol Prog Ser 72, 205-212.

Hennes, K. P. \& Simon, M. (1995). Significance of bacteriophages for controlling bacterioplankton growth in a mesotrophic lake. Appl Environ Microbiol 61, 333-340.

Hoben, H. J. \& Somasegaran, P. (1982). Comparison of the pour, spread, and drop plate methods for enumeration of Rbizobium spp. in inoculants made from presterilized peat. Appl Environ Microbiol 44, 1246-1247.

Husevåg, B. (1995). Starvation survival of the fish pathogen Aeromonas salmonicida in seawater. FEMS Microbiol Ecol 16, 25-32.

Hussong, D., Colwell, R. R., O'Brien, M., Weiss, E., Pearson, A. D., Weiner, R. M. \& Burge, W. D. (1987). Viable Legionella pneumophila not detectable by culture on agar media. Bio/Technology 5, 947-950.

Jenkins, D. E., Schultz, J. E. \& Matin, A. (1988). Starvation-induced cross protection against heat or $\mathrm{H}_{2} \mathrm{O}_{2}$ challenge in Escherichia coli. J Bacteriol 170, 3910-3914.

Jenkins, D. E., Chaisson, S. A. \& Matin, A. (1990). Starvationinduced cross protection against osmotic challenge in Eschericbia coli. J Bacteriol 172, 2779-2781.

Jones, D. M., Sutcliffe, E. M. \& Curry, A. (1991). Recovery of viable but non-culturable Campylobacter jejuni. J Gen Microbiol 137, 2477-2482.

Jouper-Jaan, Å., Goodman, A. E. \& Kjelleberg, S. (1992). Bacteria starved for prolonged periods develop increased protection against lethal temperatures. FEMS Microbiol Ecol 101, 229-236.

Kaprelyants, A. S. \& Kell, D. B. (1992). Rapid assessment of bacterial viability and vitality by rhodamine 123 and flow cytometry. $J$ Appl Bacteriol 72, 410-422.

Kaprelyants, A. S., Gottschal, J. C. \& Kell, D. B. (1993). Dormancy in non-sporulating bacteria. FEMS Microbiol Rev 104, 271-286.

Kaprelyants, A. S., Mukamolova, G. V. \& Kell, D. B. (1994). Estimation of dormant Micrococcus luteus cells by penicillin lysis and by resuscitation in cell-free spent culture medium at high dilution. FEMS Microbiol Lett 115, 347-352.

Kaspar, C. W. \& Tamplin, M. L. (1993). Effects of temperature and salinity on the survival of Vibrio vulnificus in seawater and shellfish. Appl Environ Microbiol 59, 2425-2429.

Kogure, K., Simidu, U. \& Taga, N. (1979). A tentative direct microscopic method for counting living marine bacteria. Can $J$ Microbiol 25, 415-420. 
Kondo, K., Takade, A. \& Amako, K. (1994). Morphology of the viable but nonculturable Vibrio cholerae as determined by the freeze fixation technique. FEMS Microbiol Lett 123, 170-184.

Leduc, M., Fréhel, C., Siegel, E. \& van Heijenoort, J. (1989). Multilayered distribution of peptidoglycan in the periplasmic space of Escherichia coli. J Gen Microbiol 135, 1243-1254.

Lee, K. \& Ruby, E. G. (1995). Symbiotic role of the viable but nonculturable state of Vibrio fischeri in Hawaiian coastal seawater. Appl Environ Microbiol 61, 278-283.

Lewis, P. J., Nwoguh, C. E., Barer, M. R., Harwood, C. R. \& Errington, J. (1994). Use of digitized video microscopy with a fluorogenic enzyme substrate to demonstrate cell- and compartment-specific gene expression in Salmonella enteridis and Bacillus subtilis. Mol Microbiol 13, 655-662.

van der Linden, M. P. G., de Haan, L., Hoyer, M. A. \& Keck, W. (1992). Possible role of Escherichia coli penicillin-binding protein 6 in stabilization of stationary-phase peptidoglycan. J Bacteriol 174, $7572-7578$

Linder, K. \& Oliver, J. D. (1989). Membrane fatty acid and virulence changes in the viable but nonculturable state of Vibrio vulnificus. Appl Environ Microbiol 55, 2837-2842.

McCann, M. P., Kidwell, J. P. \& Matin, A. (1991). The putative sigma factor KatF has a central role in development of starvationmediated general resistance in Escherichia coli. J Bacteriol 173, 4188-4194.

Morgan, J. A. W., Cranwell, P. A. \& Pickup, R. W. (1991). Survival of Aeromonas salmonicida in Lake Water. Appl Environ Microbiol 57, 1777-1782.

Morita, R. Y. (1993). Bioavailability of energy and the starvation state. In Starvation in Bacteria, pp. 1-23. Edited by S. Kjelleberg. New York \& London: Plenum Press.

Neidhardt, F., Bloch, P. L. \& Smith, D. F. (1974). Culture medium for Enterobacteriaceae. J Bacteriol 119, 736-747.

Nilsson, L., Oliver, J. D. \& Kjelleberg, S. (1991). Resuscitation of Vibrio vulnificus from the viable but nonculturable state. J Bacteriol 173, 5054-5059.

Nyström, T., Mården, P. \& Kjelleberg, S. (1986). Relative changes in incorporation rates of leucine and methionine during starvation survival of two bacteria isolated from marine waters. FEMS Microbiol Ecol 38, 285-292.

Nyström, T., Olsson, R. M. \& Kjelleberg, S. (1992). Survival, stress resistance, and alterations in protein expression in the marine Vibrio sp. strain S14 during starvation for different individual nutrients. Appl Environ Microbiol 58, 55-65.

Oliver, J. D. (1993). Formation of viable but nonculturable cells. In Starvation in Bacteria, pp. 239-272. Edited by S. Kjelleberg. New York \& London: Plenum Press.

Oliver, J. D. \& Bockian, R. (1995). In vivo resuscitation, and virulence towards mice, of viable but nonculturable cells of Vibrio vulnificus. Appl Environ Microbiol 61, 2620-2623.

Oliver, J. D., Nilsson, L. \& Kjelleberg, S. (1991). Formation of nonculturable cells of L'ibrio vulnificus and its relationship to the starvation state. Appl Environ Microbiol 57, 2640-2644.

Oliver, J. D., Hite, F., McDougald, D., Andon, N. L. \& Simpson, L. M. (1995). Entry into, and resuscitation from, the viable but nonculturable state by Librio vulnificus in an estuarine environment. Appl Environ Microbiol 61, 2624-2630.
Östling, J., Goodman, A. \& Kjelleberg, S. (1991). Behaviour of IncP-1 plasmids and a miniMu transposon in a marine Vibrio sp.: isolation of starvation inducible lac operon fusions. FEMS Microbiol Ecol 86, 83-94.

Postgate, J. R. \& Hunter, J. R. (1963). Acceleration of bacterial death by growth substrates. Nature 198, 273.

Proctor, L. M., Okubo, A. \& Fuhrman, J. A. (1993). Calibrating estimates of phage-induced mortality in marine bacteria: ultrastructural studies of marine bacteriophage development from onestep growth experiments. Microb Ecol 25, 161-182.

Quesnel, L. B. (1963). A genealogical study of clonal development of Escherichia coli. J Appl Bacteriol 26, 127-151.

Ravel, J., Knight, I. T., Monahan, C. E., Hill, R. T. \& Colwell, R. R. (1995). Temperature-induced recovery of Vibrio cholerae from the viable but nonculturable state: growth or resuscitation? Microbiology 141, 377-383.

Rodriguez, G. G., Phipps, D. \& Ridgway, H. F. (1992). Use of a fluorescent redox probe for direct visualization of actively respiring bacteria. Appl Environ Microbiol 58, 1801-1808.

Rose, A. S., Ellis, A. E. \& Munro, A. L. S. (1990). Evidence against dormancy in the bacterial fish pathogen Aeromonas salmonicida subsp. salmonicida. FEMS Microbiol Lett 68, 105-108.

Roszak, D. B. \& Colwell, R. R. (1987). Survival strategies of bacteria in the natural environment. Microbiol Rev 51, 365-379.

Roszak, D. B., Grimes, D. J. \& Colwell, R. R. (1984). Viable but nonrecoverable stage of Salmonella enteridis in aquatic systems. Can $J$ Microbiol 30, 334-338.

Saha, S. K., Saha, S. \& Sanyal, S. C. (1991). Recovery of injured Campylobacter jejuni cells after animal passage. Appl Environ Microbiol 57, 3388-3389.

Simpson, L. M., White, V. K., Zane, S. F. \& Oliver, J. D. (1987). Correlation between virulence and colony morphology in Vibrio vulnificus. Infect Immun 55, 269-272.

Terleckyj, B., Willet, N. P. \& Shockman, G. D. (1975). Growth of several cariogenic strains of oral streptococci in a chemically defined medium. Infect Immun 11, 649-655.

Torrella, F. \& Morita, R. Y. (1981). Microcultural study of bacterial size changes and microcolony and ultramicrocolony formation by heterotrophic bacteria in seawater. Appl Environ Microbiol 41, 518-527.

Votyakova, T. V., Kaprelyants, A. S. \& Kell, D. B. (1994). Influence of viable cells on the resuscitation of dormant cells in Micrococcus luteus cultures held in an extended stationary phase: the population effect. Appl Environ Microbiol 60, 3284-3291.

Weichart, D., Oliver, J. D. \& Kjelleberg, S. (1992). Low temperature induced non-culturability and killing of Vibrio vulnificus. FEMS Microbiol Lett 100, 205-210.

Williamson, F. A. \& Palframan, K. R. (1989). An improved method for collecting and staining microorganisms for enumeration by fluorescence light microscopy. J Microsc 154, 267-272.

Zimmermann, R., Iturriaga, R. \& Becker-Birck, J. (1978). Simultaneous determination of the total number of aquatic bacteria and the number thereof involved in respiration. Appl Environ Microbiol 36, 926-935.

Received 16 August 1995; revised 30 October 1995; accepted 27 November 1995. 